\title{
A comparison of Globigerinoides ruber calcification between upwelling and non-upwelling regions in the Arabian Sea
}

\author{
Sushant S Naik*, Shital P Godad, P Divakar Naidu and V Ramaswamy \\ CSIR-National Institute of Oceanography, Dona Paula, Goa 403 004, India. \\ ${ }^{*}$ Corresponding author. e-mail: sushant@nio.org
}

Shell weights of planktonic foraminifera species Globigerinoides ruber in the size range of 300-355 $\mu \mathrm{m}$ were measured from sediment traps in the western and eastern Arabian Sea which represent upwelling and non-upwelling conditions respectively. In the Western Arabian Sea Trap (WAST), G. ruber flux ranged from 33.3 to $437.3 \mathrm{\#} / \mathrm{m}^{2} /$ day and shell weights ranged from 6.7 to $14.2 \mu \mathrm{g}$. Whereas, in the Eastern Arabian Sea Trap (EAST), flux ranged from 0.7 to 164.6 \#/ $\mathrm{m}^{2} /$ day and shell weights ranged from 10.4 to $14.8 \mu \mathrm{g}$. Shell weights of $G$. ruber versus flux showed significant correlation at both the sites which reveals that shell calcification mainly depends on optimal growth conditions. Though the WAST and EAST location have distinct difference in $\mathrm{pCO}_{2}$ and sea surface temperature (SST), the shell weights of $G$. ruber are similar in these two regions which suggest that surface water $\mathrm{pCO}_{2}$ and SST do not show dominant influence on shell calcification on a seasonal timescale.

\section{Introduction}

Atmospheric $\mathrm{CO}_{2}$ dissolves in surface seawater and affects the equilibrium between the species, $\mathrm{H}_{2} \mathrm{CO}_{3}, \mathrm{HCO}_{3}^{-}$and $\mathrm{CO}_{3}^{=}$. The preindustrial value of atmospheric $\mathrm{CO}_{2}$ was around $280 \mathrm{ppm}$ and has increased sharply to $388 \mathrm{ppm}$ due to increases in fossil fuel combustion, deforestation and land-use change. One third of this excess atmospheric $\mathrm{CO}_{2}$ is absorbed by the ocean and causes an increase in $\left[\mathrm{H}^{+}\right]$which leads to a lowered $\mathrm{pH}$, and a decrease in $\left[\mathrm{CO}_{3}=\right]$. This makes the seawater less alkaline and is currently referred to as 'Ocean Acidification'. The surface ocean $\mathrm{pH}$ has been reported to drop on average by about $0.1 \mathrm{pH}$ units since pre-industrial levels (Byrne et al. 2010).

Attempts have been made to reconstruct the carbonate ion history from sediments of the world oceans using the planktonic foraminifera shell weight proxy (Lohmann 1995) and this proxy has been widely utilised (Broecker et al. 1999; Broecker and Clark 1999, 2001). Largely, in the above studies, the shell weights of selected planktonic foraminifer species has been successfully utilized in understanding the carbonate ion variations during the Holocene and the LGM. The surface water $\left[\mathrm{CO}_{3}=\right]$ decrease probably leads to a reduction in shell calcification (de Moel et al. 2009) and in turn surface water $\left[\mathrm{CO}_{3}^{=}\right]$has been estimated by using shell weights of planktonic foraminifera (Barker and Elderfield 2002; Naik et al. 2010). However, de Villiers (2004) notes that highest foraminiferal shell-weights are observed within the optimum ecological niche of each planktonic species and there are no simple relationships with calcite saturation, temperature or surface nutrient levels. Due to such contradictory findings it is of importance to understand what factors could be influencing shell

Keywords. Arabian Sea; $\mathrm{pCO}_{2}$; shell weights; flux; SST. 
calcification and further what could be the fate of planktonic foraminifera under high $\mathrm{CO}_{2}$ conditions.

Globigerinoides ruber is a sub-tropical, symbiont-bearing planktonic foraminifera and occurs throughout the year with high abundances during the SW monsoon followed by the north-east (NE) monsoon period (Curry et al. 1992; Conan et al. 2002; Peeters et al. 2002). Here, we compare flux and shell weights of $G$. ruber from two sediment traps from the western and eastern Arabian Sea so as to (1) understand whether optimum growth conditions influence shell calcification, and (2) whether shell calcification is affected by high ambient water $\mathrm{pCO}_{2}$. We have chosen the planktonic foraminifera species $G$. ruber as it lives throughout the year in the Arabian Sea and represents surface water conditions, and secondly, does not secrete gametogenic calcite (Hemleben and Spindler 1983).

\section{Physical settings}

The Arabian Sea is characterised by strong southwesterly monsoon winds during the northern hemisphere summer, which blow across the Arabian Sea, causing offshore Ekman transport and intense seasonal upwelling along the Oman and Somalia margins and the southwest coast of India (Wyrtki 1973; Schott 1983; Shallow 1984; Bauer et al. 1991). The upwelling process brings cold, nutrient-rich waters from a few hundred meters depth to the surface and increases the biological productivity in the euphotic zone. These SW monsoon winds and associated upwelling processes make the Arabian Sea one of the highest productive regions in the world oceans (Qasim 1982). During the NE monsoon the upwelling is suppressed but there is a convective mixing due to surface cooling in the northeast Arabian Sea (Madhupratap et al. 1996). The western Arabian Sea upwelling is more intense in comparison to its eastern counterpart. The eastern Arabian Sea in contrast is influenced by heavy precipitation during SW monsoon and is also fed by numerous rivers from the Indian subcontinent.

\section{Samples and techniques}

Planktonic foraminifera samples from two PARFLUX Mark VI sediment traps (Honjo and Doherty 1988) deployed since 1986 at two different locations were used in this study; Western Arabian Sea Trap (WAST) $\left(16^{\circ} 20^{\prime} \mathrm{N} ; 60^{\circ} 20^{\prime} \mathrm{E}\right)$ placed at $4020 \mathrm{~m}$ below sea surface and Eastern Arabian Sea Trap (EAST) $\left(5^{\circ} 37^{\prime} \mathrm{N} ; 68^{\circ} 33^{\prime} \mathrm{E}\right)$ placed at $2782 \mathrm{~m}$ below sea surface (figure 1).

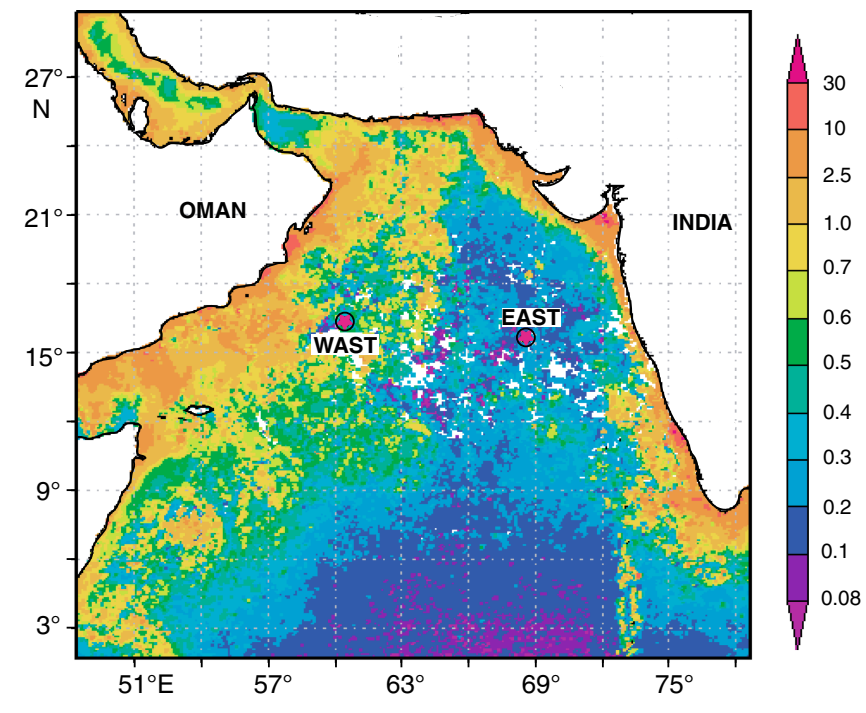

Figure 1. Composite SeaWiFS chlorophyll- $a$ concentration (in $\mathrm{mg} / \mathrm{m}^{3}$ ) image, for June-September 1998 (source: http://gdata1.sci.gsfc.nasa.gov/) with superimposed sediment trap locations.

EAST and WAST sediment traps were deployed in the year 1993 and 1997 during the cruises SO 91 and SO 119 (Schiebel et al. 2004) of RV Sonne, respectively. The EAST sediment trap was recovered in January 1995 during the RV Sagar Kanya cruise SK 98 whereas the WAST trap was recovered in May 1998 during the cruise SK 135. Samples recovered from the WAST covered the period from June 1997 to January 1998 and that from the EAST were from October 1993 to September 1994 (figure 1; table 1). The WAST sediment trap was programmed to receive consecutive samples at a duration of every 12 days, whereas the sampling days for the EAST trap were variable and ranged from 13 to 27 days. The carbonate compensation depth (CCD) in the Indian Ocean is placed at $4400 \mathrm{~m}$ water depth (Banakar et al. 1998). Though the WAST trap lies just around this depth in the Arabian Sea, SEM micrographs on the foraminifera shells do not show signs of dissolution.

At the time of deployment, the sampling cups (13 per trap) were filled with filtered seawater and mercuric chloride $\left(\mathrm{HgCl}_{2}, 3.3 \mathrm{~g} \mathrm{l}^{-1}\right)$ was added as a preservative to prevent the degradation of organic material and stop bacterial activity in the trap samples to avoid alteration of the samples. After the recovery of the trap, the samples were wet sieved on board through a $1 \mathrm{~mm}$ mesh nylon sieve. The fraction $<1 \mathrm{~mm}$ was split into 16 aliquots using a rotary splitter on board, filtered through $0.4 \mu \mathrm{m}$ Nuclepore filters, oven-dried at $40^{\circ} \mathrm{C}$ and weighed. The dried samples were further sieved through a 
Table 1. Sampling periods, flux and shell weights for the western and eastern Arabian Sea sediment traps.

\begin{tabular}{|c|c|c|c|c|c|c|c|c|}
\hline \multirow[b]{2}{*}{$\begin{array}{l}\text { Sl. } \\
\text { no. }\end{array}$} & \multicolumn{4}{|c|}{ WAST } & \multicolumn{4}{|c|}{ EAST } \\
\hline & Start date & End date & $\begin{array}{c}\text { Flux } \\
\left(\# / \mathrm{m}^{2} / \text { day }\right)\end{array}$ & $\begin{array}{c}\text { Shell } \\
\text { weights }(\mu \mathrm{g})\end{array}$ & Start date & End date & $\begin{array}{c}\text { Flux } \\
\left(\# / \mathrm{m}^{2} / \text { day }\right)\end{array}$ & $\begin{array}{c}\text { Shell } \\
\text { weights }(\mu \mathrm{g})\end{array}$ \\
\hline 1 & 01/06/1997 & 13/06/1997 & - & - & 18/10/1993 & 14/11/1993 & 8.3 & - \\
\hline 2 & $13 / 06 / 1997$ & $25 / 06 / 1997$ & 33.3 & 6.7 & 14/11/1993 & 11/12/1993 & - & - \\
\hline 3 & $25 / 06 / 1997$ & 07/07/1997 & 158.7 & 10.2 & 11/12/1993 & $24 / 12 / 1993$ & - & - \\
\hline 4 & $07 / 07 / 1997$ & 19/07/1997 & 66.7 & 8 & $24 / 12 / 1993$ & 07/01/1993 & - & - \\
\hline 5 & 19/07/1997 & $31 / 07 / 1997$ & 213.3 & 11.5 & $07 / 01 / 1994$ & $20 / 01 / 1994$ & - & - \\
\hline 6 & $31 / 07 / 1997$ & $12 / 08 / 1997$ & 138.7 & 9.7 & $20 / 01 / 1994$ & 03/02/1994 & 14.4 & 12.4 \\
\hline 7 & $12 / 08 / 1997$ & $24 / 08 / 1997$ & 437.3 & 11.4 & 03/02/1994 & $16 / 02 / 1994$ & 0.7 & - \\
\hline 8 & $24 / 08 / 1997$ & 05/09/1997 & - & - & 16/02/1994 & 02/03/1994 & 6.2 & 11.8 \\
\hline 9 & 05/09/1997 & 17/09/1997 & 426.7 & 13.8 & 02/03/1994 & 29/03/1994 & 13.5 & 12.4 \\
\hline 10 & $17 / 09 / 1997$ & 29/09/1997 & 368 & 14.1 & 29/03/1994 & $25 / 04 / 1994$ & 21.5 & 11.7 \\
\hline 11 & $29 / 09 / 1997$ & $11 / 10 / 1997$ & - & - & $25 / 04 / 1994$ & $22 / 05 / 1994$ & 57.6 & 12.9 \\
\hline 12 & $11 / 10 / 1997$ & $23 / 10 / 1997$ & - & - & $22 / 05 / 1994$ & 04/06/1994 & - & - \\
\hline 13 & $23 / 10 / 1997$ & 04/11/1997 & - & - & 04/06/1994 & $19 / 06 / 1994$ & - & - \\
\hline 14 & 04/11/1997 & $16 / 11 / 1997$ & - & - & 19/06/1994 & 02/07/1994 & 11.2 & 12.6 \\
\hline 15 & 16/11/1997 & $28 / 11 / 1997$ & 304 & 14.2 & 02/07/1994 & 16/07/1994 & 5.2 & 12.3 \\
\hline 16 & $28 / 11 / 1997$ & $10 / 12 / 1997$ & - & - & $16 / 07 / 1994$ & 29/07/1994 & 23.6 & 10.4 \\
\hline 17 & $10 / 12 / 1997$ & $22 / 12 / 1997$ & 229.3 & 10.6 & 29/07/1994 & $12 / 08 / 1994$ & 164.6 & 14.8 \\
\hline 18 & $22 / 12 / 1997$ & 03/01/1998 & 325.3 & 11.1 & $12 / 08 / 1994$ & $25 / 08 / 1994$ & 10.5 & - \\
\hline 19 & 03/01/1998 & 15/01/1998 & 192 & 9.9 & $25 / 08 / 1994$ & 08/09/1994 & - & - \\
\hline 20 & 15/01/1998 & $27 / 01 / 1998$ & 128 & 12.5 & 08/09/1994 & 21/09/1994 & - & - \\
\hline 21 & & & & & 21/09/1994 & 05/10/1994 & - & - \\
\hline
\end{tabular}

$150 \mu \mathrm{m}$ sieve and the individual species were quantified under a stereo-zoom binocular microscope. Foraminiferal fluxes of G. ruber (white) were calculated using the counts, splits, sediment trap aperture and duration of each sample using a standard procedure (Curry et al. 1992).

For shell weight measurements, the coarse material was further sieved in the size range of $300-$ $355 \mu \mathrm{m}$. Approximately 30 G. ruber (white) shells were picked from this size fraction under a stereozoom binocular microscope and weighed on a microbalance $(1 \sigma$ precision: $\pm 1.5 \mu \mathrm{g}, \mathrm{n}=10)$.

\section{Results and discussion}

In the western Arabian Sea, the flux of $G$. ruber ranged from 33.3 to $437.3 \# / \mathrm{m}^{2} /$ day while in eastern Arabian Sea it ranged from 0.7 to 164.6 \#/ $\mathrm{m}^{2} /$ day (figure $2 \mathrm{a}$ and $\mathrm{c}$ ). Higher flux values were encountered during the south-west (SW) monsoon, specifically during July-August at both the sites. Foraminiferal fluxes were two-fold higher in the western than the eastern Arabian Sea. The higher flux of $G$. ruber in the western Arabian Sea during SW monsoon is a result of upwelling. The shell weight record for the western Arabian Sea is available from June to January whereas that of the eastern Arabian Sea is from January to August. The gaps in shell weight record occur due to the unavailability of enough shells for weighing. The shell weights of $G$. ruber ranged from 6.7 to $14.2 \mu \mathrm{g}$ in the western Arabian Sea while they ranged from 10.4 to $14.8 \mu \mathrm{g}$ in the eastern Arabian Sea (figure $2 \mathrm{a}$ and $\mathrm{c}$ ).

The Arabian Sea is known to be a region with highest particle flux to the deep sea in comparison to the global flux (Honjo et al. 2008). Measurements made since 1983 show that the western Arabian Sea in particular contributed to an average organic carbon flux (normalised to $2 \mathrm{~km}$ of water depth) of $553 \mathrm{mmol} \mathrm{C} / \mathrm{m}^{2} / \mathrm{yr}$ and an inorganic flux of $424 \mathrm{mmol} \mathrm{C} / \mathrm{m}^{2} / \mathrm{yr}$ (Honjo et al. 2008). In the eastern Arabian Sea, organic and inorganic carbon flux of 234 and $171 \mathrm{mmol} \mathrm{C} / \mathrm{m}^{2} / \mathrm{yr}$ have been noted (Honjo et al. 2008). The foraminiferal flux is also known to greatly increase during the SW monsoon (Curry et al. 1992; Mohan et al. 2006). During 1986-1987, Curry et al. (1992) noted a G. ruber flux of $\sim 1000 \# / \mathrm{m}^{2} /$ day during the SW and $\sim 2000 \# / \mathrm{m}^{2} /$ day during the NE monsoon season at the WAST and $\sim 700 \# / \mathrm{m}^{2} /$ day during the SW monsoon and very low flux during the NE monsoon at EAST. Our study, however, shows a higher $G$. ruber flux during the SW monsoon and lower during the NE monsoon at both the locations. 


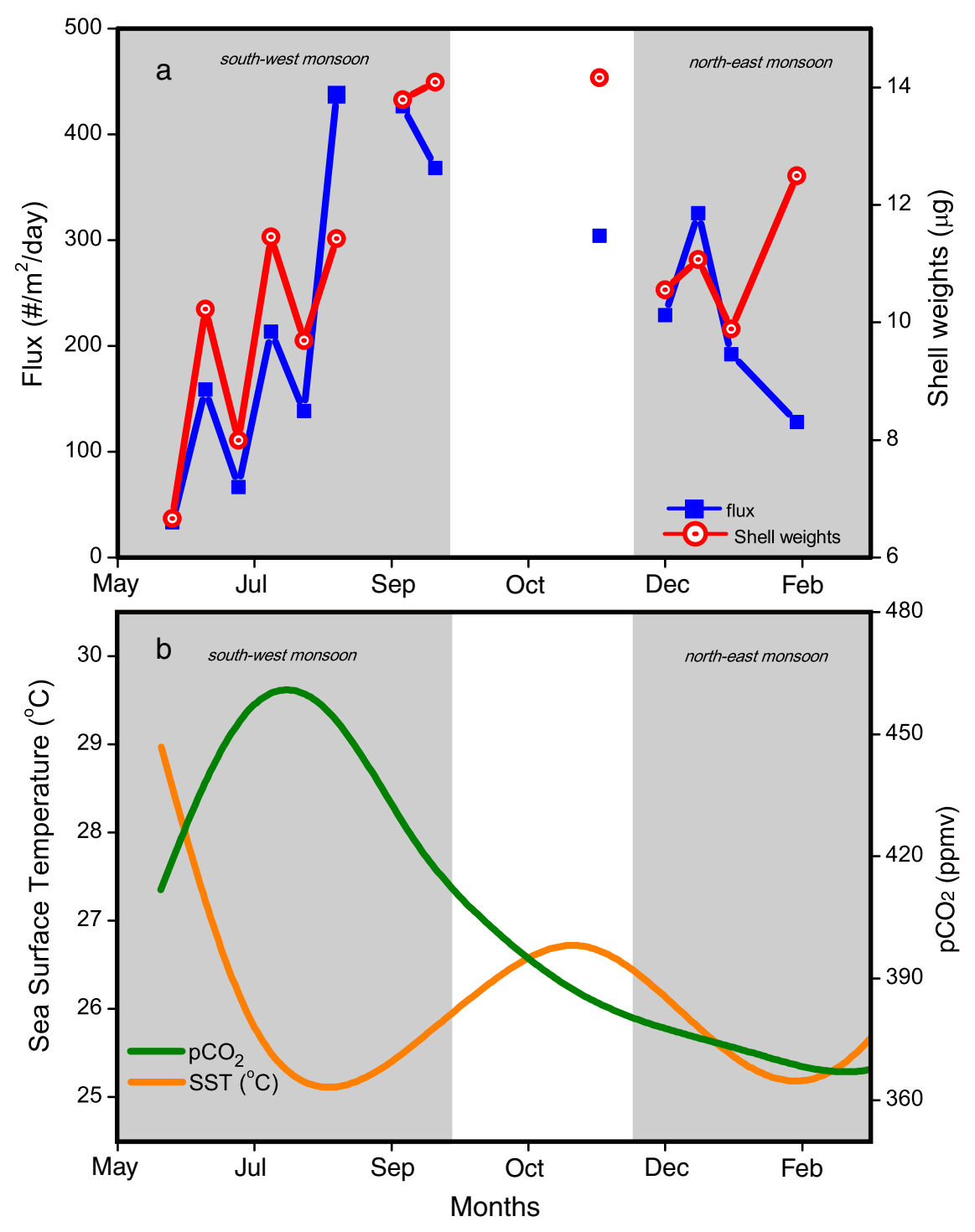

Figure 2. (a) Shell weights and flux of G. ruber at WAST, (b) $\mathrm{pCO}_{2}$ and SST variation in western Arabian Sea, (c) shell weights and flux of $G$. ruber at EAST and (d) $\mathrm{pCO}_{2}$ and SST variation in eastern Arabian Sea.

Every organism is adapted to specific optimum environmental conditions which include temperature, salinity, depth habitat, etc., under which it is able to flourish (Schmidt et al. 2006). We can logically assume that an increase in flux of a foraminiferal species is an indicator of optimal conditions for that species growth. In order to understand whether optimum growth conditions control shell calcification, we compared G. ruber shell weights and fluxes. We observe significant correlations between $G$. ruber shell weights and fluxes in the western $\left(r^{2}=0.58 ; n=13 ; p=0.001\right)$ and the eastern $\left(r^{2}=0.60 ; n=9 ; p=0.0046\right)$ Arabian Sea (figure $3 \mathrm{a}$ and $\mathrm{b}$ ). However, the correlation in the eastern Arabian Sea is weaker as it is highly dependent on a single data point which falls in the upwelling period. The increase in shell weights of $G$. ruber coupled with the increase in its flux (figure 2a and c) suggests that shell calcification is enhanced when conditions are favourable for this species to grow. This finding implies that shell calcification primarily depends upon optimum growth conditions and is in line with results of de Villiers (2004). Conan (2006), reported shell weights of G. ruber from a western Arabian Sea sediment trap (Site 905, lying further south of the present study location) to be in the range of 9-14.7 $\mu \mathrm{g}$ (250$355 \mu \mathrm{m}$ size fraction) with lower shell weights during the upwelling season and no relationship with the flux. Our findings are thus in contrast, with higher shell weights during the upwelling season and significant correlation with flux.

We also examined the possible influence of factors such as ambient water $\mathrm{pCO}_{2}$ and sea surface 

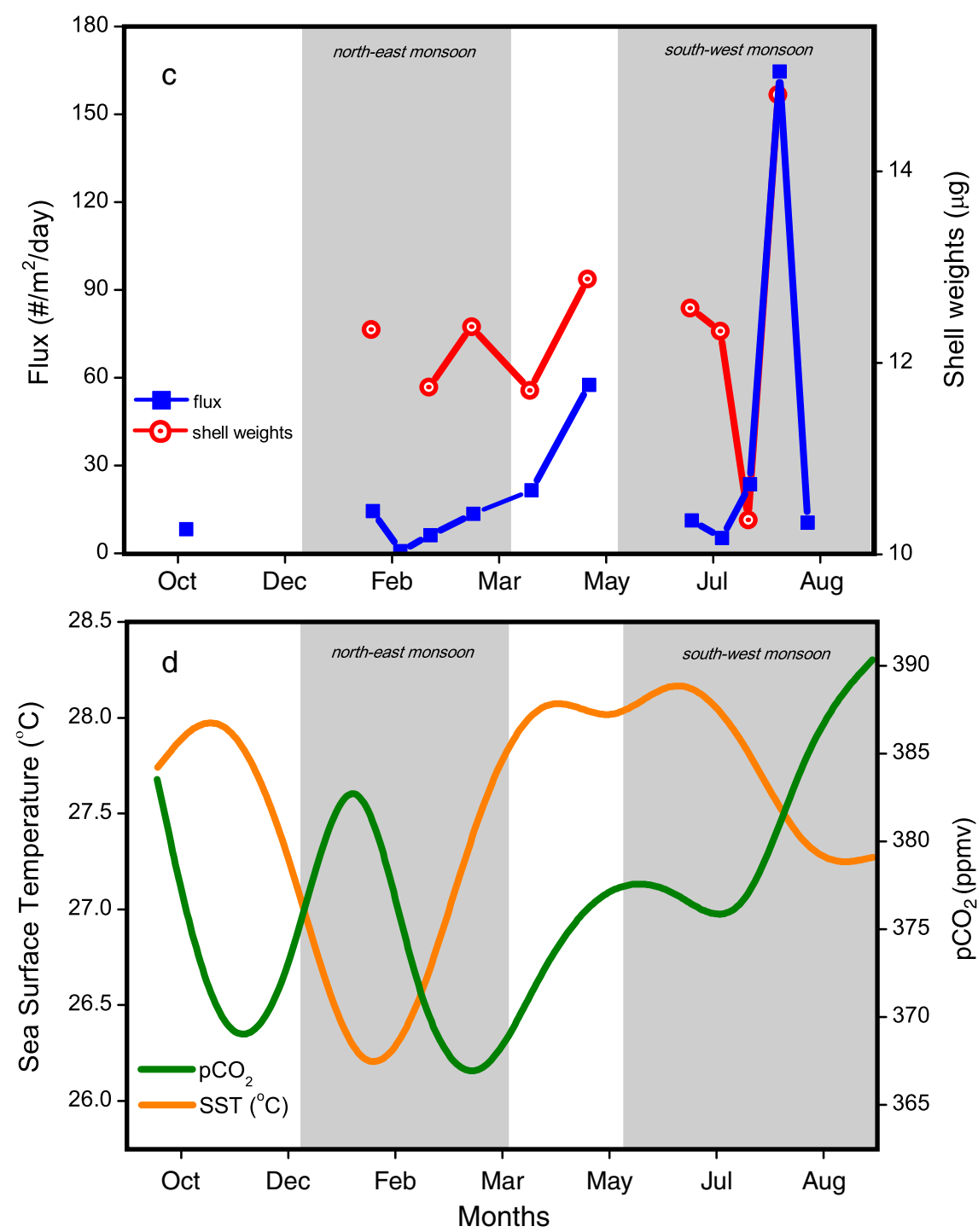

Figure 2. (Continued)

temperature (SST) on shell calcification at both these sites. The $\mathrm{pCO}_{2}$ and SST were calculated for the months wherein the flux and shell weight data are available and the values are monthly averages for the years 1970-2000, obtained from the database of Takahashi et al. (2009). The calculated $\mathrm{pCO}_{2}$ values of surface waters in the western Arabian Sea ranges from 366 ppm during the nonupwelling period to $464 \mathrm{ppm}$ during the upwelling period, whereas, those on the eastern side range from 365 to $390 \mathrm{ppm}$ (figure $2 \mathrm{~b}, \mathrm{~d}$ ). We have compared 30-year averages of $\mathrm{pCO}_{2}$ and SST to shell weight data of a single year because in-situ measurements were not made at the time of sample collection. However, the averages depict a general pattern of $\mathrm{pCO}_{2}$ and SST variations in a year. This is also supported by the data of Lendt et al. (2003), from the western Arabian Sea, collected in the same year as the sediment trap samples of 1997-1998. SSTs were lower during the monsoon season whereas the $\mathrm{pCO}_{2}$ values were highest during the same period reaching a maximum of $\sim 650$ ratm (Lendt et al. 2003). During the SW monsoon, the $\mathrm{pCO}_{2}$ in the western Arabian Sea attains much higher values compared to the eastern Arabian Sea due to intense upwelling of sub-surface $\mathrm{CO}_{2}$ enriched waters. The SSTs in the western Arabian Sea show a larger variability from $25^{\circ}$ to $30^{\circ} \mathrm{C}$ as compared to the eastern side which range from $26^{\circ}$ to $28^{\circ} \mathrm{C}$ (figure $2 \mathrm{~b}, \mathrm{~d}$ ) (Takahashi et al. 2009). Our observation shows that there is no covariance between $\mathrm{pCO}_{2}$ and shell weights or SSTs and shell weights. In the WAST, shell weights averaged $10.7 \mu \mathrm{g}$ for the SW monsoon and $11 \mu \mathrm{g}$ for the NE monsoon. The average $\mathrm{pCO}_{2}$ for the same periods are 440 and 372 ppmv, respectively. This indicates that the shell weight differences are negligible for a $\mathrm{pCO}_{2}$ change of $68 \mathrm{ppmv}$. 

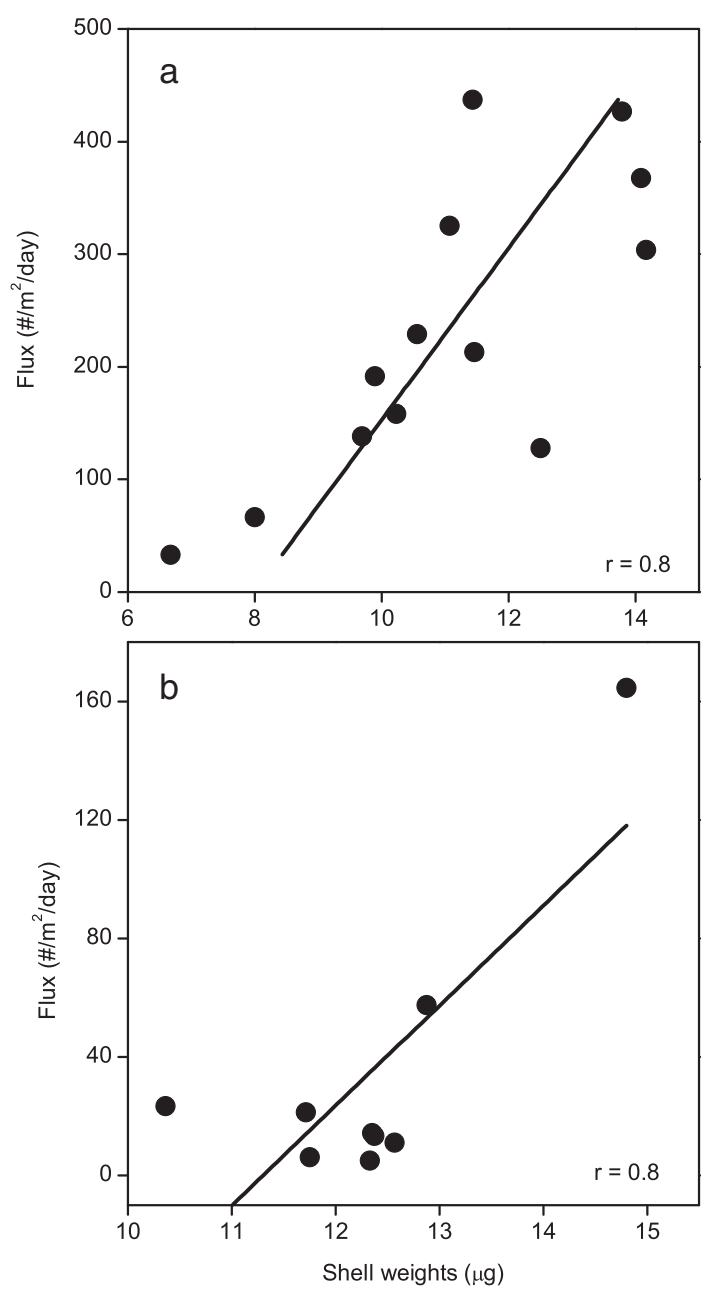

Figure 3. Correlations between $G$. ruber shell weights and G. ruber flux at (a) WAST and (b) EAST.

Likewise in the EAST, shell weights $/ \mathrm{pCO}_{2}$ averaged $12.5 \mu \mathrm{g} / 382 \mathrm{ppmv}$ and $12.2 \mu \mathrm{g} / 372 \mathrm{ppmv}$ for the SW and NE monsoon, respectively. Since shell weights are seen to be influenced by the higher flux during upwelling, we have calculated fluxweighted averages of shell weights for the two sites, WAST and EAST, which were 12 and $13.2 \mu \mathrm{g}$, respectively.

Although $\mathrm{pCO}_{2}$ and SST are distinct between WAST and EAST, the flux weighted shell weight averages are similar which corroborates the fact that $\mathrm{pCO}_{2}$ and SST may not have a dominant control on shell calcification. Beer et al. (2010) have demonstrated that surface water $\left[\mathrm{CO}_{3}^{=}\right]$does not exert a dominant control on $G$. ruber and $G$. bulloides shell weights in the western Arabian Sea which is in line with our findings. They have also shown that $G$. ruber is negatively correlated to surface water $\left[\mathrm{CO}_{3}^{=}\right]$. They reasoned it to the fact that, across an upwelling zone, temperature, salinity, alkalinity, $\left[\mathrm{CO}_{3}^{=}\right],[\mathrm{DIC}]$, light, nutrients, and food supply vary in conjunction with one another.
Therefore shell weights may depend on other factors and still be correlated to $\left[\mathrm{CO}_{3}^{=}\right]$though it is not a dominant control. However, the present study shows that shell weights are correlated to flux of $G$. ruber and hence, optimal growth conditions are the possible factors in controlling shell calcification.

Further, the different morphotypes of G. ruber, namely G. ruber sensu stricto (s.s.) and G. ruber sensu lato (s.l.) could probably influence the relationship between flux and shell weights. $G$. ruber s.s., is a surface dweller and G. ruber s.l., a sub-surface dweller. So during periods of intense upwelling the sub-surface dweller may dominate (Wang 2000) and may cause a bias in shell weights. This could be the possible reason for stronger correlations between flux and shell weights in the upwelling (WAST) region in comparison to the non-upwelling (EAST) region.

\section{Conclusions}

Planktonic foraminifer G. ruber flux and shell weights were measured from the sediment trap samples from the western and eastern Arabian Sea. G. ruber flux and shell weights exhibit significant positive correlation during SW and NE monsoons in the western and eastern Arabian Sea suggesting that optimum growth conditions for G. ruber prevailed during monsoons which were the primary influence on shell calcification. Strikingly, there was no distinct difference in shell weights of $G$. ruber between the western and eastern Arabian Sea. The lack of influence of elevated $\mathrm{CO}_{2}$ and lowered SST as a result of intense upwelling in the western Arabian Sea, on $G$. ruber shell weights suggests that temperature or carbonate ion may not be the primarily control on $G$. ruber shell calcification in these regions on a seasonal timescale. Our study proposes that it is further necessary to elucidate the exact factors which promote shell calcification of a particular foraminiferal species during the monsoon season.

\section{Acknowledgements}

The authors thank Dr S Shetye, Director, National Institute of Oceanography for support and encouragement. This is NIO Contribution No. 5315.

\section{References}

Banakar V K, Parthiban G, Patan J N and Jauhari P 1998 Chemistry of surface sediments along a northsouth transect across the equator in the central Indian basin: An assessment of biogenic and detrital influences on elemental burial on the seafloor; Chem. Geol. 147 $217-232$. 
Barker S and Elderfield H 2002 Foraminiferal calcification response to glacial-interglacial changes in atmospheric $\mathrm{CO}_{2} ;$ Sci. $297833-836$.

Bauer S, Hitchcock G L and Olson D B 1991 Influence of monsoonly-forced Ekman dynamics upon surface layer depth and plankton biomass distribution in the Arabian Sea; Deep-Sea Res. A 38 531-553.

Beer C J, Schiebel R and Wilson P A 2010 Testing planktonic foraminiferal shell weight as a surface water $\left[\mathrm{CO}_{3}^{2-}\right]$ proxy using plankton net sample; Geol. 38(2) 103-106, doi: 10.1130/G30150.1.

Broecker W S and Clark E $1999 \mathrm{CaCO}_{3}$ size distribution: A paleocarbonate ion proxy; Paleoceanogr. 14 596-604.

Broecker W S, Clark E, Mc Corkle D C, Peng T-H, Hajdas I and Bonani G 1999 Evidence for a reduction in the carbonate ion content of the deep-sea during the course of the Holocene; Paleoceanogr. 14 744-752.

Broecker W S and Clark E 2001 An evaluation of Lohmann's foraminifera weight dissolution index; Paleoceanogr. 16(5) 531-534.

Byrne R H, Sabine M, Feely R A and Liu X 2010 Direct observations of basin-wide acidification of the north Pacific Ocean; Geophys. Res. Lett. 37 L02601, doi: 10.1029/2009GL040999.

Conan S M-H, Evanova E M and Brummer G-J A 2002 Quantifying carbonate dissolution and calibration of foraminiferal dissolution indices in the Somali Basin; Mar. Geol. 182 325-349.

Conan S M-H 2006 Calibration of planktic foraminifera proxies for paleoproductivity and seasonal variability in the western Arabian Sea; PhD dissertation, Faculty of Earth and Life Sciences, Vrije Universiteit, Amsterdam, 225p.

Curry W B, Osterman D R, Guptha M V S and Ittekkot V 1992 Foraminiferal production and monsoonal upwelling in the Arabian Sea: Evidence from sediment traps; In: Upwelling Systems; Evolution Since the Early Miocene (eds) Summerhays C P, Prell W L and Emeis K C; Geol. Soc. of London, England, pp. 93-106.

de Moel H, Ganssen G M, Peeters F J C, Jung S J A, Kroon D, Brummer G J A and Zeebe R E 2009 Planktic foraminiferal shell thinning in the Arabian Sea due to anthropogenic ocean acidification?; Biogeosci. 6 1917-1925.

de Villiers S 2004 Occupation of an ecological niche as the fundamental control on the shell-weight of calcifying planktonic foraminifera; Mar. Biol. 144(1) 45-50.

Hemleben C and Spindler M 1983 Recent advances in research on living planktonic foraminifera; Utrecht Micropal. Bull. 30 141-170.

Honjo W and Doherty K W 1988 Large aperture time series oceanic sediment traps: Design objectives, construction and application; Deep-Sea Res. 35 133-149.

Honjo S, Manganini S, Krishfield R A and Francois R 2008 Particulate organic carbon fluxes to the ocean interior and factors controlling the biological pump: A synthesis of global sediment trap programs since 1983; Progr. Oceanogr. 76 217-285.

Lendt R, Thomas H, Hupe A and Ittekkot V 2003 Response of the near-surface carbonate system of the northwestern Arabian Sea to the southwest monsoon and related biological forcing; J. Geophys. Res. 108 3222, doi: 10.1029/2000JC000771.

Lohmann G P 1995 A model for variation in the chemistry of planktonic foraminifera due to secondary calcification and selective dissolution; Paleoceanogr. 10 445-447.

Madhupratap M, Kumar S P, Bhattathiri P M A, Kumar M D, Raghukumar S, Nair K K C and Ramaiah N 1996 Mechanism of the biological response to winter cooling in the Arabian Sea; Nature 384 549-551.

Mohan R, Verma K, Mergulhao L P, Sinha D K, Shanavas S and Guptha M V S 2006 Seasonal variations of pteropods from the Western Arabian Sea sediment traps; Geo-Mar. Lett. 26 265-273.

Naik S S, Naidu P D, Govil P and Godad S 2010 Relationship between weights of planktonic foraminifer shell and surface water $\mathrm{CO}_{3}^{\overline{ }}$ concentration during the Holocene and Last Glacial Period; Mar. Geol. 275 278-282.

Peeters F J C, Brummer G-J A and Ganssen G 2002 The effect of upwelling on the distribution and stable isotope composition of Globigerina bulloides and Globigerinoides ruber (planktic foraminifera) in modern surface waters of the NW Arabian Sea; Glob. Planet. Change 34(3-4) 269-291.

Qasim S Z 1982 Oceanography of the northern Arabian Sea; Deep-Sea Res. A 29 1041-1068.

Schiebel R, Zeltner A, Treppke U F, Waniek J J, Bollmann J, Rixen T and Hemleben C 2004 Distribution of diatoms, coccolithophores and planktic foraminifers along atrophic gradient during SW monsoon in the Arabian Sea; Mar. Micropal. 51 345-371, doi: 10.1016/j.marmicro.2004.02.001.

Schmidt D N, Lazarus D, Young J R and Kucera M 2006 Biogeography and evolution of body size in marine plankton; Earth-Sci. Rev. 78 239-266.

Schott F 1983 Monsoon response of the Somalia Current and associated upwelling; Progr. Oceanogr. 12(3) 357-381.

Shallow J C 1984 Some aspects of the physical oceanography of the Indian Ocean; Deep-Sea Res. A 31 639-650.

Takahashi T, Sutherland S C and Wanninkhof R et al. 2009 Climatological mean and decadal changes in surface ocean $\mathrm{pCO}_{2}$, and net sea-air $\mathrm{CO}_{2}$ flux over the global oceans; Deep-Sea Res. II 56 554-577.

Wang W 2000 Isotopic signals in two morphotypes of Globigerinoides ruber (white) from the South China Sea: Implications for monsoon climate change during the last glacial cycle; Paleogeogr. Paleoclimatol. Paleoecol. 161 381-394.

Wyrtki K 1973 Physical oceanography of the Indian Ocean; In: The Biology of the Indian Ocean (ed.) Zeitzschelp B (New York: Springer-Verlag), pp. 18-36. 